\title{
Shaping the National Body: Physical Education and the Transformation of German Nationalism in the Long Nineteenth Century
}

\author{
Daniel Tröhler
}

Abstract - The following article reconstructs the curricular story of physical education between the Prussian prohibition (1820) and reintroduction (1842) and broad dissemination of 'gymnastic exercises' between 1842 and 1871 and its full implementation around 1900 in Germany, focusing on the interrelation between constitutional reforms, nationalism and the development of a state-directed educational system, directed towards making the loyal future citizens. The successive formation of a German nation-state is being understood as the historical context of the implementation of gymnastics in the school curriculum; a process that in its success depended on the rise of nationalism as a dominant political ideology in the course of the nineteenth century.

Keywords • nation-states, nationalism, curriculum, physical education, nineteenth century

On June 6, 1842, King Frederick William IV of Prussia declared in a patriotic cabinet order that henceforth "gymnastic exercises" would be part of the curriculum for Prussia's upper high schools, higher city schools and teacher seminars. ${ }^{1}$ It was a first step in the institutionalisation of gymnastics as a 'normal' school subject-a process that was completed with the foundation of a German nation-state, the German Reich, in 1871, when gymnastics, or Turnen, became an ordinary part of the elementary school curriculum.

The creation and introduction of a new and ordinary school subject in the curricula for all education levels (below the university level) between 1842 and 1871 represents a history that reveals much about nationalism, constitutionalism, nation-building, curriculum and the making of future citizens, and it unveils how visions of social order in both dimensions, social and cultural, are translated into educational measures designed to implement and sustain these visions.

The story behind the school subject "gymnastic exercises" is rather neglected in history of education in general and in curriculum history in particular, but even less

Revised paper presented at the panel "The Body Between the Protestant Souls and the Embodiment of the Emerging Nation-States in the Nineteenth Century: Physical Education in a Cross-Cultural Perspective (Sweden, Germany, and Switzerland)" at the 38th annual conference of the International Standing Conference for the History of Education (ISCHE), Chicago, IL, August 17-20, 2016.

1 Hermann T. Wangemann, Schulordnung nebst Einrichtungs- und Lehrplan für die preussische Volksschule: Erste Abtheilung, welche die Schulordnung und die äusserlichen Einrichtungen betriff, zusammengestellt von Dr. Wangemann (Berlin: Wohlgemuth, 1856).

Daniel Tröhler is Professor in Foundations of Education at the Department of Education, University of Vienna, Austria.

Email:daniel.troehler@univie.ac.at

In order to maintain the integrity of the peer review process, editor Johannes Westberg has mediated the contacts between the author (who is one of the editors of this issue) and the reviewers of this article. 
in sports history. ${ }^{2}$ Prussia shows, however, how much this example provides insight into the mechanisms of aligning the modern school to dominant social or national needs, expressed in the fabrication of the desired future citizens of the envisaged social order. After 1842, a part of the citizens, here still reduced to the future male citizen attending higher schooling, had to be physically exercised and trained, and from 1871 on, all children were exposed to physical exercises at school.

The official introduction of gymnastic exercises in 1842 mentioned above was insofar peculiar, as it set an end to a ban imposed by the predecessor of King Frederick William IV, Frederick William III in 1820, which expelled gymnastic exercises not only from the schools but from the whole public sphere. The story between the prohibition (1820) and reintroduction (1842) and broad dissemination of gymnastic exercises' between 1842 and 1871 and its full implementation around 1900 will be reconstructed in this article, focusing on the interrelation between constitutional reforms, nationalism and the development of a mass educational system. The successive formation of a German nation-state was the historical context of the implementation of gymnastics in the school curriculum; a process that in its success depended on the rise of nationalism as a dominant political ideology in the course of the nineteenth century.

\section{Gymnastics and the German nation}

With the Treaties of Tilsit in 1807 signed by Napoleon and Tsar Alexander, Prussia lost about half of its pre-war territory and was occupied by the French troops. The Prussian defeat also meant the end of the Holy Roman Empire of the German Nation, existing since 1512, and the reactions in Germany were, among others, deliberately fomented seeds of national feelings, or nationalism, with the aim of uniting the German nation as a more valuable opponent to the French nation. Reform-oriented statesmen such as Baron vom Stein, who aimed at transforming and modernising at least Prussia, approached poets, writers and scholars and motivated them to support the reform movement by means of public propaganda. ${ }^{3}$

Participating in this endeavour to create a "national myth"4 were, among others, the philosopher Johann Gottlieb Fichte, the theologian Friedrich Schleiermacherboth of them centrally involved in the creation of the University of Berlin, today the Humboldt-University ${ }^{5}$ - the dramatist Heinrich von Kleist ${ }^{6}$ and last but not least, the rather unsuccessful former divinity student Friedrich Ludwig Jahn. Jahn was an

2 For instance Henning Eichberg, "Body Culture and Democratic Nationalism: 'Popular Gymnastics' in Nineteenth-Century Denmark," The International Journal of the History of Sport 12, no. 2 (1995), 108-24; Else Trangbeak, "Danish Gymnastics: What's so Danish about the Danes?" The International Journal of the History of Sport 13, no. 2 (1996), 203-14, Kyle Grimes, "'Fit Audience, Though Few:' Romanticism and Physical Education in the 1820s," Romanticism 19, no. 3 (2013), 261-72.

3 Otto W. Johnston, Der deutsche Nationalmythos: Ursprung eines politischen Programms (Stuttgart: Metzler, 1990).

4 Johnston (1990).

5 For more details on the context of the foundation of today's Humboldt University, see Heinz-Elmar Tenorth, "The University of Berlin: A Foundation Between Defeat and Crisis, Philosophy and Politics," Bildungsgeschichte: International Journal for the Historiography of Education 4, no. 1 (2014), $11-28$.

6 And also the educational policy maker Johann Wilhelm Süvern, the publisher Georg Reimer, the historians Arnold Heeren and Heinrich Luden. 
assistant teacher at the famous Plamann Institute in Berlin headed by the Lutheran minister Johann Ernst Plamann, which was the major institutional hub of the Swiss Johann Heinrich Pestalozzi's educational 'method' in Berlin.

All of the participants were Lutherans, and the majority of them were sons of Lutheran ministers and had themselves studied theology; Schleiermacher simply translated his Pietist visions of sacrifice, fraternity and community into the German Volk und Vaterland, the German people and fatherland. ${ }^{7}$ Deeply embedded in evangelical Protestantism, they were agents of the cultural shift towards 'educationalisation of the world', that is, defining the future in an educational(ised) discourse, aiming educationally at transforming the inner soul of the individual exposed to a changing world. ${ }^{8}$ The paradigm figure of this movement was Pestalozzi, ${ }^{9}$ and his most noble propagandist in Germany was the said philosopher Fichte, who in his famous Addresses to the German Nation in 1808 explained the military defeat of Prussia against France as resulting from a long-running moral decay in Prussia ${ }^{10}$ that needed to be countered by thorough educational reform following the method developed by Pestalozzi; and in this context Fichte asked explicitly for physical education, too. ${ }^{11}$

Obviously, Fichte's educational argument arose out of a nationalist concern, and his idea of the "nation" was based on a commonality of language. Yet, according to Fichte, the German nation was not only one among others but also was in fact predestined to morally lead the world, because (in his view) in contrast to all of the Roman languages, the German language had remained an unadulterated language. According to Fichte, the purity of the German language allowed the educated German to recognise original, that is, unspoiled, truths ${ }^{12}$ according to which the world should be designed.

This triad of original truths, the future and education became the centre of the German 'national myth' during the French occupation (1806-1814). It proved to be successful not only in creating a particular nationalist imagination but also in the ambition of combatting the French occupiers by trained soldiers serving to implement this imagined nation. In this nascent German nationalism the need grew for physical exercises that would help create a paramilitary reserve army on behalf of the German nation, and to this end, already existing concepts for physical education ${ }^{13}$

7 "The Volk, the people, is God's creation and loyalty to the people is equated with loyalty to God" (as cited in Hans-Werner Hahn and Helmut Berding, Gebhardt: Handbuch der deutschen Geschichte - Band 14: Reformen, Restauration und Revolution 1806-1848/49, 10th ed. (Stuttgart: Klett-Cotta, 2010), 120).

8 Daniel Tröhler, "Educationalization of Social Problems and the Educationalization of the Modern World," in Encyclopedia of Educational Philosophy and Theory, ed. Michael A. Peters (Dordrecht: Springer, 2016).

9 Daniel Tröhler, Pestalozzi and the Educationalization of the World (New York: Palgrave Pivot, 2013).

10 Johann Gottlieb Fichte, Addresses to the German Nation, trans. and ed. Gregory Moore (Cambridge: Cambridge University Press, 2008; original work published 1808), xx.

11 Fichte (2008), 24-32, 119, 125.

12 Fichte (2008), 57-58.

13 Peter Villaume, "Von der Bildung des Körpers in Rücksicht auf die Vollkommenheit und Glückseligkeit des Menschen, oder über die physische Erziehung insonderheit," in Allgemeine Revision des gesammten Schul- und Erziehungswesens von einer Gesellschaft praktischer Erzieher, vol. VIII (Vienna: Rudolf Gräffer und Compani, Schulbuchhandlung, 1787), 211-492; Johann Christoph Friedrich GutsMuths, Gymnastik für die Jugend. Enthalten eine praktische Anweisung zu Leibesübungen (Schnepfenthal: Verlage der Buchhandlung der Erziehungsanstalt, 1793). 
were ideologically translated into a nationalist, paramilitary discourse that won momentum on the occasion of the official conscription or draft, which defined every male citizen as a potential soldier, in 1813 .

The most prominent figure in this movement was Friedrich Ludwig Jahn, mentioned above, who was a fierce and fundamental nationalist and author of Deutsches Volksthum (German Folklore/Tradition/Values) ${ }^{14}$ By claiming etymological roots, Jahn even invented a name for these kinds of national-military exercises, namely, Turnen, ${ }^{15}$ which is usually translated into English as 'gymnastics'. Jahn was able to connect Fichte's linguistic philosophy with his own military ambitions, conferring the honour of absolute national necessity on the idea of Turnen. ${ }^{16}$

Jahn's vision of gymnastics did not aim at drilling the future soldiers ${ }^{17}$ in the style of the Prussian army of the eighteenth century that attracted Foucault's attention. ${ }^{18}$ Jahn's aim was obviously not submissive fighters with slavish obedience but rather nationally minded fraternal warriors characterised by a particular sentiment or attitude, the turnerische Gesinnung, or "gymnastic attitude" or spirit. ${ }^{19}$ This gymnastic attitude acted as a link between inward purification, often labelled Bildung, and the outer, social or national world, and this attitude was characterised by a collectively shared strong sense of equality of German 'brotherhood' beyond any social distinctions.

\section{Nation-building and school reform}

Between 1807 and 1813, when Napoleon was defeated in Russia, German nationalism was a movement of intellectuals, organised in secret societies like the German Association founded in 1810 by Ludwig Jahn or the League of Virtue (Tugendbund) founded in $1808^{20}$ devoted to physical exercises, among other things. ${ }^{21}$ Starting with hiking and playing games in and around Berlin, in spring 1811 Jahn and his nationalistic associates organised the first public gymnastic exercises in the Hasenheide park in the south of Berlin. A movement emerged in which men demonstrated the strength and suppleness of their bodies in public, expressing the willingness of the German youth to defend the nation against the French occupiers. The sexual dimension of these exhibitions of the purified German bodies becomes apparent, in particular, by the fact that the French were generally sexually stigmatised as "obscene;" ${ }^{22}$ French women were in principle equated to prostitutes who aimed to infect

14 Friedrich Ludwig Jahn, Deutsches Volksthum (Lübeck: Niemann und Comp., 1810).

15 Friedrich Ludwig Jahn and Ernst Eiselen, Die deutsche Turnkunst zur Einrichtung der Turnplätze (Berlin: [s.n.], 1816), XXVII.

16 Turnen as a word and physical activity still exists today and has to be seen in contrast to 'sports', invented by the British as civic leisure activity.

17 Jahn and Eiselen (1816), 229.

18 Michel Foucault, Discipline and Punish: The Birth of the Prison, trans. Alan Sheridan (New York: Random House, 1977), 138, 315.

19 Christiane Eisenberg, "English sports" und deutsche Bürger: Eine Gesellschaftsgeschichte 1800-1939 (Paderborn: Schöningh, 1999).

20 Leighton S. James, Witnessing the Revolutionary and Napoleonic Wars in German Central Europe (New York: Palgrave Macmillan, 2013).

21 Johann August Otto Leopold Lehmann, Der Tugendbund, aus den hinterlassenen Papieren des Mitstifters Professor Dr. Hans Friedrich Gottlieb Lehmann (Berlin: Haude- und Spenersche Buchhandlung, 1867), 171.

22 Ernst Moritz Arndt, Blick aus der Zeit auf die Zeit (Germanien [Frankfurt]: Eichenberg, 1814). 
the bodies of Germans with germs. ${ }^{23}$ Starting in Berlin, disciples of this nationalistic movement were sent out to other parts of Prussia to establish similar activities. In 1817/1818, Prussia had some 100 gymnastic associations with around 6,000 gymnasts.

With the aid of nationalist policy reformers, ${ }^{24}$ gymnastics started to enter the school curricula right after the end of the Congress of Vienna (in 1815). Die Deutsche Turnkunst zur Einrichtung der Turnplätze dargestellt (The German Art of Gymnastics Depicted for the Establishment of Gym Fields), published by Ludwig Jahn in 1816 together with another teacher at the Plamann Institute, Ernst Eiselen, became an official textbook in the public schools and guided teachers in conducting gymnastics with their students. With the full support of Minister Johann Wilhelm Süvern, Eiselen became responsible for the training of the future gymnastics teachers, and Jahn was appointed chief gymnastics inspector, observing gymnastics instruction in all of Prussia.

Despite this success story of Turnen, King Frederick William III of Prussia prohibited gymnastics in public and in the schools shortly thereafter in 1820. What had happened? As a matter of fact, in the eyes of the contemporaries the nationalist movement was a liberal and progressive movement that advocated both the idea of human equality (as long as the human beings were German) and the idea of a German union, that is, the dissolution of all of the duchies, principalities and kingdoms and the creation of one new national German Empire. Both concerns, culminating in the need to adopt a national constitution, were rejected by the German nobilities, who had agreed at the Congress in Vienna in 1815 on the creation of the German Confederation, guaranteeing the sovereignty of all of the member states. Most of the political authorities in these member states hesitated to pass a constitution that had been demanded by both the gymnastics movement and the new fraternities, and the actual power holders soon found a good reason to counter these requests for a new constitution.

This reason was the murder in 1819 of the conservative council of state, August von Kotzebue, by Karl Ludwig Sand, a (Lutheran) theology student and Turner at the Hasenheide. The conservative monarchs of the loose German Confederation reacted almost immediately with the Carlsbad Decrees, which were reactionary restrictions banning nationalist fraternities, removing liberal university professors and expanding the censorship of the press. It is in this context that King Frederick William III pronounced his ban on gymnastics (Turnen), and several leaders of the gymnastics movement were sent to jail, among them Ludwig Jahn. The encompassing educational reforms that were underway were stopped in 1819, and their major promoter, Johann Wilhelm Süvern, lost influence.

But physical exercises were not completely banned from the schools, especially not outside of Prussia. In the time of the ban, Lutheran theologian and former soldier Johann Adolf Ludwig Werner, for instance, introduced gymnastics for women into the school curriculum in the Kingdom of Saxony ${ }^{25}$ and propagated gymnastics

23 Eisenberg (1999), 116-17.

24 Like Friedrich von Schuckmann, Hans Graf von Bülow or Karl August von Hardenberg; see Jahn and Eiselen (1816), XLVI.

25 Johann Adolf Werner Werner, Gymnastik für die weibliche Jugend oder weibliche Körperbildung für die Gesundheit, Kraft und Anmuth (Meißen: Goedsche, 1834). 
as a crucial part of public education. ${ }^{26}$ To prevent any suspicion, the activists refrained from using the concept of Turnen and used instead the Germanised version

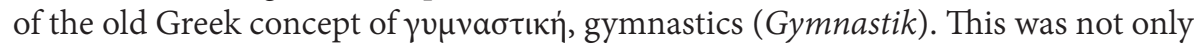
an expression of opportunism but also indicated a different style of physical exercises that may be seen as related to medical gymnastics, closer to the Swedish tradition of Pehr Henrik Ling than to Ludwig Jahn.

In the time of the ban, the tight connection between gymnastics and nation-building was dissolved, but the value of healthy, strong male bodies, in particular with regard to military interests, remained appreciated. The Turnen ban came to an end when, after the death of Frederick William III in 1840, his oldest son, Frederick William IV, came into power. The nationalists saw in him a ray of hope, which he reliably disappointed. ${ }^{27}$ But with a new fundamental conflict with France, the Rhine crisis of $1840 / 1841$, when the French reclaimed the territories to the left of the Rhine river, a new broad tide of nationalism arose. This new tide was not connected to Germany at first hand but to Prussia, for these disputed territories had been under Prussian rule. It is in this context that August Heinrich Hoffmann von Fallersleben, a university professor of Germanic philology, wrote the "Song of Germany" (Deutschlandlied) that later (and up to today) became the official national anthem. The first lines (today omitted from the anthem) are: "Germany, Germany above all else / Above all else in the world / when, for protection and defence / it always stands brotherly together."

In the minds of the nationalists, the Prussian folk required military spirit and ability, and it was military leaders in particular that pressed for the standardised introduction of gymnastics at all Prussian schools. ${ }^{28}$ It is precisely in this heated militarist nationalist context that Turnen, as indicated above, found wider acceptance, and Jahn became rehabilitated and was now called Turnvater Jahn [gym father Jahn]. ${ }^{29}$ Turnen was first introduced in Prussian upper high schools, higher city schools and teacher seminars - and then, after 1871, in all schools of the German empire.

\section{The constitutional German nation-states, curriculum and Turnen}

Depending on the historiography, the enthronement of Frederick William IV of Prussia in 1840 was in the middle or in the beginning of an epoch called the Vormärz, literally translated as pre-March. Often this movement is believed to have started in the wake of the July Revolution of 1830 in Paris, triggering a period of political uprising. It culminated in the German Revolution that broke out in March 1848 with the claim of creating a democratically unified German nation-state based on a constitution-a movement that was suppressed by Prussian and Austrian troops in autumn 1849.

A few months prior to this suppression, in March 1849, the self-constituted assembly of the 'revolutionaries' proclaimed a constitutional draft called the Frankfurt Constitution, foreseeing the creation of a smaller-scale Germany, that is, without Austria and under the leadership of the Prussian monarchy. Frederick William IV

26 Johann Adolf Werner Werner, Das ganze der Gymnastik oder ausführliches Lehrbuch der Leibeserziehung nach den Grundsätzen der besseren Erziehung zum öffentlichen und besonderen Unterricht (Meissen: Goedsche, 1834).

27 He refused to follow most of the neighbouring states in adopting a constitution.

28 Karl-Heinz Schodrok, Preussische Turnpolitik (Berlin, Germany: epubli, 2013), 336-43.

29 Morgenblatt für gebildete Stände, Nr. 92 (17 April 1847), 366. 
rejected this solution and himself imposed a new constitution. ${ }^{30}$ It guaranteed essential political rights to all Prussians, ${ }^{31}$ but left much power to the wealthy citizens and foremost to the nobility, who often lacked both education and wealth. And it was not national, that is, a part of creating a German nation-state, as it was focused on the territory of Prussia only. The imposed constitution was obviously not a result of democratic deliberation, but it was a constitution nonetheless. It expressed the dominant conservative vision of social order and at the same time formally provided legalised citizenship, even if the notion of Prussian "citizen" was hardly used and their spheres of (political) influence scarce: The Royal subjects had become, formally, constitutionally defined citizens understood as entities with legal status.

As the rebellion of the Vormärz had been borne by intellectuals and teachers, a large purge followed, somehow similar to the purge in Turkey after the failed putsch in July 2016, and the reforms affected not least the education system, which was to be fully controlled by the state authorities. Some 470,000 Turners as part of the liberal-national movement emigrated from Germany, ${ }^{32}$ many of them to the United States. The corresponding elementary school regulations ${ }^{33}$ that followed the dynastic conservative constitution of 1851 aimed at complete enrolment of all Prussian children in schools with a standardised curriculum comprising Religion first of all, German Language (reading and writing), some Mathematics and Singing. ${ }^{34}$ In particular, the pupils had no Latin in school, although its mastery was required for transition to Gymnasium; Latin was at the centre of the curriculum of the fee-paying 'prep school' (Vorschule) - prep school understood here as the preparation or preliminary stage leading to Gymnasium. Additionally, the curriculum did not foresee any physical exercises in the schools save in the teacher seminaries, where they had to be based explicitly on the gymnastics developed by the Swede Pehr Henrik Ling (see the article by Johannes Westberg in this issue) and Adolf Spiess (see the article by Rebekka Horlacher in this issue), and had to aim at young people being a virtuous part of a "valiant and brave people (Volk)." ${ }^{35}$ This explicit reference to Ling and foremost to Spiess is significant, for Spiess fit exactly into the extremely conservative mood of the times after $1848^{36}$ and highlighted distance to Turnvater Jahn with his nationalist and German-fraternal ambitions connected to gymnastics. Already in 1848, the German Turners who remained in Germany were divided into a comparatively unpolitical Deutsche Turnerbund (German gymnastics union) and the republican-democratic Demokratische Turnerbund (Democratic gymnastics union); many of the latter escaped from Germany in the context of the restoration politics after 1849.

30 On 5 December 1848 , and a revision on 31 January 1850.

31 For instance, it provided religious freedom (Article 13), allowed civil marriage (Article 19), declared the principle of academic autonomy and freedom (Article 20), declared freedom of opinion and abolished censorship (Article 27), allowed unlimited right of assembly and the right of petition (Articles 29, 30, 32), and guaranteed the secrecy of correspondence (Article 33). And Article 21 declared that the education of the youth would take place in public schools and that school attendance was compulsory.

32 Schodrock (2013), 502.

33 Ferdinand Stiehl, Die drei Preußischen Regulative vom 1., 2. und 3. Oktober 1854 über Einrichtung des evangelischen Seminar-, Präparanden- und Elementarunterrichts (Berlin: Vilhelm Hertz, 1854).

34 Given the very minor importance of mathematics, an average Prussian pupil had to become mainly a hardworking, disciplined and devoted German-speaking Christian Prussian.

35 Stiehl (1854), 47.

36 Schodrock (2013), 391-402. 
Nevertheless, after 1850, there were different more or less independent German territorial states - heirlooms of the 1806 dissolved Holy Roman Empire of the German Nation-with (conservative) constitutions that directed the school systems in order to fabricate loyal subjects in now constitutional states. The expansion of the education system was admirable, but gymnastics was not (yet) a school subject on the elementary school level. Increased pressure for the cultural 'normalisation' of gymnastics and its thorough educationalisation expressed in its integration into the curriculum of the elementary school came from the German Turner movement and its activities. Already in 1856, the Turners had published the Deutsche Turnzeitung (German Gymnastics Journal) in which they talked about the Volk (people), fatherland, nation and even of Germany, but only reluctantly of "unity." ${ }^{37}$ In 1860 , the first German gymnastics festival (Turnfest) was organised in Coburg, and a year later in Berlin; and the leading ideas were both physical and political, aiming at German unity. On the occasion of the Coburg festival, they decided to unite all German Turners in one German association, an event that was implemented in 1868 and named the German Gymnasts (Turnerschaft). From 1863, the Turners published a biannual statistical yearbook of the gymnastics associations. ${ }^{38}$

Parallel to this process of public institutionalisation, members advocated for a more systematic representation of Turnen in the elementary schools. For instance, in 1862, Carl Friedrich Hausmann, a teacher at the teacher seminar in Weimar and head of the local gymnastics association, published Das Turnen in der Volksschuleein Beitrag zur allgemeinen Einführung geregelter Körperübungen (Gymnastics in the Elementary School - a Contribution to the General Introduction of Regulated Physical Exercises) ${ }^{39}$ followed eleven years later with an extended second edition, Das Turnen in der Volksschule mit Berücksichtigung des Turnens in den höheren Schulen ein nach dem neuesten Standpunkte der Turnkunde bearbeitetes Lehrbuch..$^{40}$ In the city of Aachen, the local government made two hours of Turnen per week an official part of the school curriculum. ${ }^{41}$ In the same year, Prussia standardised the training of future gymnastics teachers in the elementary schools and published guidelines for gymnastics education in Prussian elementary schools, ${ }^{42}$ aiming at combining educational and military interests. ${ }^{43}$ A year later, the modes of certifying gymnastics teachers were laid down. ${ }^{44}$

37 Svenja Goltermann, Körper der Nation: Habitusformierung und die Politik des Turnens 1860-1890 (Göttingen: Vandenhoeck und Ruprecht, 1998), 72.

38 Georg Hirth, Statistisches Jahrbuch der Turnvereine Deutschlands (Leipzig: Keil, 1863 and subsequent).

39 Carl F. Hausmann, Das Turnen in der Volksschule - ein Beitrag zur allgemeinen Einführung geregelter Körperübungen (Weimar: Böhlau, 1862).

40 Carl F. Hausmann, Das Turnen in der Volksschule mit Berücksichtigung des Turnens in den höheren Schulen ein nach dem neuesten Standpunkte der Turnkunde bearbeitetes Lehrbuch (Weimar: Böhlau, 1873).

41 Königliche Regierung in Aachen, “Turn-Unterricht in Elementarschulen,” Centralblatt für die gesammte Unterrichts-Verwaltung in Preußen 7, no. 6 (1865), 366.

42 Leitfaden für den Turn-Unterricht in den Preussischen Volksschulen (Berlin: Wilhelm Herp, 1862).

43 Ferdinand Stiehl, "Ausbildung von Turn-Lehrern für Elementarschulen, " Centralblatt für die gesammte Unterrichts-Verwaltung in Preußen 7, nos. 9/10 (1865), 589-600.

44 Heinrich von Mühler, "Befähigungszeugnisse für Elementarlehrer zur Ertheilung des Turn-Unterrichts," Centralblatt für die gesammte Unterrichts-Verwaltung in Preußen 8, no. 3 (1866), 148-50. 
These accelerated developments took place in a broader territorial-political context of German nation-building, which was organised between two ideologies of the Großdeutsches Reich, including Austria, and the Kleindeutsches Reich, excluding Austria. Due to the Second Schleswig War (1864), which gave rise to a national movement in Denmark, ${ }^{45}$ and the Austro-Prussian War in 1866, the German Bund had been dissolved, followed by the North German Confederation (1866-1871). The Confederation stood under the leadership of Prussia, and on the occasion of the Franco-Prussian War four years later (1870-1871), the French were defeated and the German Empire was founded. In 1871, the dream of a unified German nation (with the exclusion of the Catholic, multilingual Austrian Empire) had formally come true, which in turn meant that the "nation" was not legitimated merely by a shared German language. The "imagined community" 46 of the German nation had to be constructed differently.

The German Empire's (Deutsches Reich) constitutional monarchy was under the leadership of the Prussian kings, first with Otto von Bismarck as Chancellor. In his early years, Bismarck had been educated at the Plamann Institute in Berlin (mentioned above), with its emphasis on Turnen, or gymnastics; and he had been given religious instruction and confirmed by the nationalist and pietistic Friedrich Schleiermacher in 1831. The nationalisation-or the mental and cultural national unification-of Germany was expedited, and the education system reformed, expanded and bureaucratised-all financially supported by France's war penalty. ${ }^{47}$ This new, reformed school played a crucial role in the making of the German nationalist citizenry, supporting, for some decades euphorically and enthusiastically, the outbreak of the First World War in 1914. The young men, upon leaving school, were physically trained and well prepared to fight, as the meanwhile thoroughly institutionalised Turnen gymnastics had taken more and more of a military turn. Ideologically, they were kindled by the nationalist intellectuals. ${ }^{48}$ One of the emergent mandarins of German education in the twentieth century, Eduard Spranger, held a speech addressing youth (An die Jugend) in 1914, in which he pointed to the need for a "spirit of duty and self-sacrifice," as the historical situation-the start of the First World War-had revealed one fundamental claim: "There is something for which one can die!" 49

\section{Curriculum and the making of loyal citizens of the German Reich}

By the time the German Reich was proclaimed in 1871, Turnvater Friedrich Ludwig Jahn had been dead for almost 30 years. Backed up by the new nationalism in the

45 See also Trangbaek (1996), 211.

46 Benedict Anderson, Imagined Communities: Reflections on the Origin and Spread of Nationalism (London: Verso, 1991).

47 The French were obliged by the Treaty of Frankfurt (May 10, 1871) to pay a war indemnity of 5 billion gold francs in 5 years; the last instalment of the indemnity was paid in September 1873, ahead of schedule.

48 Such as Eucken (see Rudolf Eucken, Die weltgeschichtliche Bedeutung des deutschen Geistes (Stuttgart/Berlin: Deutsche Verlags-Anstalt, 1914) and Sombart (see Werner Sombart, Händler und Helden. Patriotische Besinnungen (Munich/Leipzig: Duncker \& Humblot, 1915)).

49 Eduard Spranger, “An die Jugend,” Der Säemann: Monatsschrift für Jugendbildung und Jugendkunde 5 (1915), 386-93. 
context of the German Reich (Reichsnationalismus), thorough educational reform took place. Already on 31 October 1872, Minister of Education and Arts, Adalbert Falk, published the new General Provisions on the reorganisation of German mass schooling and teacher education. ${ }^{50}$ Falk declared, among other things, that from now on gymnastics ought to be taught to boys in all elementary schools. ${ }^{51}$ The general appreciation for gymnastics had become obvious and expressed itself, for instance, in the declaration of mandatory gymnastics for the middle and higher schools for girls, ${ }^{52}$ in recommendations for rural elementary school teachers, ${ }^{53}$ and in a call to introduce gymnastics to the curriculum for deaf-mutes, too, ${ }^{54}$ a demand that was officially supported by the Ministry of Education. ${ }^{55}$ In the 1880 s, girls in elementary schools were also taught gymnastics, whereby this was aimed at strengthening the female body to promote "grace and beauty of movement," whereas the missing inner unity of Germany was labelled as a lack of "masculinity," which was to be generated through gymnastics (for boys) at school. ${ }^{56}$ In this essential expansion of gymnastics, the teachers and officials were not left alone: The Turner Georg Heinrich Weber published a book for teachers and administrators on the fundamentals of gymnastics education for boys and girls in 1881 and contributed to the full implementation of gymnastics in the German curricula. ${ }^{57}$

New teachers were trained in gymnastics, but older teachers had to be particularly trained in four-week courses. In 1875, a group of 231 elementary school teachers took this official course, a year later, 244 , and in 1877, 246. A year later, 114, in 1880, some 272 , and from that point the numbers decreased, in 1881 to 175 , then to 69 , a year later, in 1883, to $101 .{ }^{58}$ By the time William I, the first German Emperor, died in 1888, gymnastics or Turnen had been almost fully established in the German curricula, including all levels, grades, the two sexes and also the disabled. However, at this

50 Adalbert Falk, "Allgemeine Bestimmungen des Königl. Preuss. Ministers der geistlichen, Unterrichts- und Medicinal-Angelegenheiten vom 15. October 1872, betreffend das Volksschule-, Präparanden und Seminar-Wesen," Centralblatt für die gesammte Unterrichts-Verwaltung in Preußen 14, no. 10 (1872), 585-97.

51 Falk (1872), 588, 597, 630.

52 "Protocolle über die im August 1873 im Königlich Preussischen Unterrichts-Ministerium gepflogenen das mittlere und höhere Mädchenschulwesen betreffenden Verhandlungen," Centralblatt für die gesammte Unterrichts-Verwaltung in Preußen 15, no. 10 (1873), 582.

53 W. Laus, "Vorschläge zur Förderung des Turnens in den Landschulen," Die Verhandlungen der Deutschen Turnlehrer-Versammlung und des Turnlehrertages des Deutschen Turnlehrer-Vereins; [Beilage zur] Monatsschrift für das Turnwesen mit besonderer Berücksichtigung des Schulturnens, der Turnspiele und verwandter Übungen 19 (1890), 23-27.

54 Arthur Gutzmann, Das Turnen der Taubstummen: Ein Vortrag, gehalten am 12. März 1878 im Berliner Turnlehrer-Verein (Berlin: Angerstein, 1878).

55 Sydow, "Schrift von Gutzmann: Das Turnen der Taubstummen," Centralblatt für die gesamte Unterrichts-Verwaltung in Preußen, 20, no. 11 (1878), 626.

56 Gustav von Gossler, "Umfang des Mädchenturnens," Centralblatt für die gesammte Unterrichts-Verwaltung in Preußen 25, no.7 (1883), 435.

57 Georg H. Weber, Grundzüge des Turnunterrichts für Knaben und Mädchen in Volks- und Mittelschulen; Ein Hilfs- und Handbuch für Schulbehörden, Lehrer und Turnlehrer (Munich: Zentral-Schulbücher-Verlag, 1881).

58 Centralblatt für die gesammte Unterrichts-Verwaltung in Preußen 18 (1876), 110, 672; Centralblatt 20 (1878), 100; Centralblatt 21 (1879), 286; Centralblatt 22 (1880), 298; Centralblatt 23 (1881), 226, 626; Centralblatt 25 (1883), 578. 
point it was not yet decided which reasoning behind advocating gymnastics (German democratic unity; health in a medical sense; military strength) was to dominate the curricular legitimation and pedagogical configuration of gymnastics. With the enthronement of Wilhelm II as the new German Emperor in 1888, things became clearer. Wilhelm II's passionate love for military strength and pomp left no doubts. On the occasion of a site visit to the Royal Institute for Gymnastics Teachers' Training College in Berlin in 1890 he told the students that he was

\begin{abstract}
extraordinarily happy with what I have just seen [...]. In this manner [italics added] gymnastics will indeed promote the physical training of the people, and I am grateful, if the pleasure of the love for gymnastics is more and more introduced to the youth [...]. I have confidence in the Gymnastics Associations that they will contribute their share to prevent the people from subversive [socialist] tendencies. And in that sense [italics added] I am grateful for the promotion of gymnastics. ${ }^{59}$
\end{abstract}

No wonder then, that Turnen eventually had become a firm and explicitly "equal" component of the curricula of all school levels and for all the Germans involved in the education system of the German Reich. ${ }^{60}$ That is, after 60 years of fighting and ideological detours, Turnen had become a fully acknowledged and socially and culturally appreciated part of the curricula of the German nation-state, designed to form the German unified national body_-strong, monarchic and anti-Semitic, ${ }^{61}$ and sceptical of, if not hostile to, both the modern sciences and Western democracy.

The advocacy for gymnastics had begun as part of a liberal nationalism of the time that opposed both the French and the pluralism of mostly unconstitutional monarchic German states, and it became more accepted and implemented the more that German unity became real. The anti-French motive remained and was supplemented with anti-Semitism, but the liberal ideas of nationalism drifted more and more to social liberalism and social democracy and were to be replaced by new nationalism in the context of the German Reich (Reichsnationalismus): conservative, right-wing, monarchic, militaristic and lacking the idea of popular sovereignty as legitimation of the Reich ${ }^{62}$ The progressing mutual penetration of the military and the social realms of life enforced gymnastics in school. The gymnastics lessons for the middle and higher elementary school and in teacher education were increased from two to three lessons a week, and teachers were advised to conduct additional physical exercises on all other days as well, aiming at strengthening the national strength (Volkskraft) ${ }^{63}$ A few years before the outbreak of the First World War-in the context of the im-

59 Quoted in: Christa Berg, Handbuch der deutschen Bildungsgeschichte - Band IV: 1870-1918. Von der Reichsgründung bis zum Ende des Ersten Weltkriegs (Munich: Beck, 1991), 504.

60 Allgemeine Bestimmungen über das preußische Volksschul-, Präparanden- und Seminar-Wesen vom 15. Oktober 1872 (Neuwied: Heuser, 1897), 23.

61 Hartmut Becker, Antisemitismus in der Deutschen Turnerschaft (St. Augustin: Academia Richarz, 1980).

62 Hans-Ulrich Wehler, Deutsche Gesellschaftsgeschichte - Dritter Band: 1849-1914 (Munich: Beck, 1995).

63 August von Trott zu Solz, "Einführung der dritten Turnstunde auf der Mittel und Oberstufe der Volksschulen; allgemeine Einführung der Übungen für das tägliche Turnen; Aufgaben des Turnunterrichts," Centralblatt für die gesamte Unterrichts-Verwaltung in Preußen 52, no. 7 (1910), 597-98. 
mense German military armament, especially of the Navy-there was no doubt that gymnastics education at school was an ideal preparation for the "use of weapons" in the "training of the strong and fit for military service youth." 64

The visions of the national were tightly linked to the Lutheran idea of inward freedom and to military strength, and the militarised body played a crucial role in implementing this vision. The increased importance of and general esteem for the gymnastic clubs (Turnvereine) with their mass events went along with the increased institutionalisation of gymnastics as an 'equal' school subject. Whereas the philological subjects and history connected the spirit (Geist) of the students to true cultural and spiritual idea(l)s of the German nation, it was gymnastics (Turnen) that brought them corporally and politically together in the German Reich as an incarnation of the idea(l)s of the German nation. Turnen, the disputed emerging school subject for more than a half a century, had found its curricular place, as it did in many other countries, but it also found its very own cultural configurational peculiarity, its curricular distinctiveness from other national trajectories of curriculum development. Different cultural and political aspirations were expressed with this new 'equal' school subject, and it aimed at very different kinds of loyal citizens to be fabricated via a reformed school system, materialised in their respective curricula. ${ }^{65}$ The 'product' was remarkable. As soon as the First World War was declared, the young loyal citizens fought to be drafted into the respective armies and to kill the enemy across the national borders that had become the dialectical geographical demarcation line, marking off dangerous otherness and the sacred identity for which so many loyal citizens were willing to die. ${ }^{66}$

64 Wever, "Anleitung zum Knabenturnen in Volksschulen ohne Turnhalle," Centralblatt für die gesamte Unterrichts-Verwaltung in Preußen 51, no. 2 (1909), 241.

65 Daniel Tröhler, "Curriculum History in Europe: A Historiographic Added Value," Nordic Journal of Educational History 3, no.1 (2016b), 3-24.

66 Anthony D. Smith, Chosen Peoples: Sacred Sources of National Identity (Oxford: Oxford University Press, 2003). 


\section{References}

Allgemeine Bestimmungen über das preußische Volksschul-, Präparanden- und Seminar-Wesen vom 15. Oktober 1872. Neuwied: Heuser, 1897.

Anderson, Benedict. Imagined Communities: Reflections on the Origin and Spread of Nationalism. London: Verso, 1991.

Arndt, Ernst Moritz. Blick aus der Zeit auf die Zeit. Germanien [Frankfurt]: Eichenberg, 1814.

Becker, Hartmut. Antisemitismus in der Deutschen Turnerschaft. St. Augustin: Academia Richarz, 1980.

Berg, Christa. Handbuch der deutschen Bildungsgeschichte - Band IV: 1870-1918. Von der Reichsgründung bis zum Ende des Ersten Weltkriegs. Munich: Beck, 1991.

Centralblatt für die gesammte Unterrichts-Verwaltung in Preußen. Im Auftrag des Herrn Ministers der geistliche, Unterrichts- und Medicinal-Angelegenheiten und unter Benutzung der amtlichen Quellen herausgegeben von Stiehl. Berlin: Verlag Wilhlm von Herz, 1859 and subsequent.

Eisenberg, Christiane. "English sports" und deutsche Bürger: Eine Gesellschaftsgeschichte 1800-1939. Paderborn: Schöningh, 1999.

Eucken, Rudolf. Die weltgeschichtliche Bedeutung des deutschen Geistes. Stuttgart/ Berlin: Deutsche Verlags-Anstalt, 1914.

Falk, Adalbert. "Allgemeine Bestimmungen des Königl. Preuss. Ministers der geistlichen, Unterrichts- und Medicinal-Angelegenheiten vom 15. October 1872, betreffend das Volksschule-, Präparanden und Seminar-Wesen." Centralblatt für die gesammte Unterrichts-Verwaltung in Preußen 14, no. 10 (1872), 585-97.

Fichte, Johann Gottlieb. Addresses to the German Nation, translated and edited by Gregory Moore. Cambridge: Cambridge University Press, 2008 (Original work published 1808).

Foucault, Michel. Discipline and Punish: The Birth of the Prison, translated by Alan Sheridan. New York: Random House, 1977 (Original work published 1975).

Goltermann, Svenja. Körper der Nation: Habitusformierung und die Politik des Turnens 1860-1890. Göttingen: Vandenhoeck und Ruprecht, 1998.

Gossler, Gustav von. "Umfang des Mädchenturnens." Centralblatt für die gesammte Unterrichts-Verwaltung in Preußen 25, no.7 (1883), 435-36.

GutsMuths, Johann Christoph Friedrich. Gymnastik für die Jugend: Enthalten eine praktische Anweisung zu Leibesübungen. Schnepfenthal: Verlage der Buchhandlung der Erziehungsanstalt, 1793.

Gutzmann, Arthur. Das Turnen der Taubstummen: Ein Vortrag, gehalten am 12. März 1878 im Berliner Turnlehrer-Verein. Berlin: Angerstein, 1878.

Hahn, Hans-Werner and Helmut Berding. Gebhardt: Handbuch der deutschen Geschichte. Band 14: Reformen, Restauration und Revolution 1806-1848/49, 10th ed. Stuttgart: Klett-Cotta, 2010.

Hausmann, Carl F. Das Turnen in der Volksschule - ein Beitrag zur allgemeinen Einführung geregelter Körperübungen. Weimar: Böhlau, 1862.

Hausmann, Carl F. Das Turnen in der Volksschule mit Berücksichtigung des Turnens in den höheren Schulen ein nach dem neuesten Standpunkte der Turnkunde bearbeitetes Lehrbuch. Weimar: Böhlau, 1873.

Hirth, Georg. Statistisches Jahrbuch der Turnvereine Deutschlands. Leipzig: Keil, 1863 and subsequent. 
Jahn, Friedrich Ludwig. Deutsches Volksthum. Lübeck: Niemann und Comp., 1810. Jahn, Friedrich Ludwig, and Eiselen Ernst. Die deutsche Turnkunst zur Einrichtung der Turnplätze. Berlin: [s.n.], 1816.

James, Leighton S. Witnessing the Revolutionary and Napoleonic Wars in German Central Europe. New York: Palgrave Macmillan, 2013.

Johnston, Otto W. Der deutsche Nationalmythos: Ursprünge eines politischen Programms. Stuttgart: Metzler, 1990.

Königliche Regierung in Aachen. “Turn-Unterricht in Elementarschulen.” Centralblatt für die gesammte Unterrichts-Verwaltung in Preußen 7, no.6 (1865), 366.

Laus, W. "Vorschläge zur Förderung des Turnens in den Landschulen." Die Verhandlungen der Deutschen Turnlehrer-Versammlung und des Turnlehrertages des Deutschen Turnlehrer-Vereins; [Beilage zur] Monatsschrift für das Turnwesen mit besonderer Berücksichtigung des Schulturnens, der Turnspiele und verwandter Übungen 19 (1890), 23-27.

Lehmann, August. Der Tugendbund: Aus den hinterlassenen Papieren des Mitstifters Professor Dr. Hans Friedrich Gottlieb Lehmann. Berlin: Haude- und Spenersche Buchhandlung, 1867.

Leitfaden für den Turn-Unterricht in den Preussischen Volksschulen. Berlin: Wilhelm Herp, 1862.

Morgenblatt für gebildete Stände. Nr. 92 (17 April 1847), 366.

Mühler, Heinrich von. "Befähigungszeugnisse für Elementarlehrer zur Ertheilung des Turn-Unterrichts." Centralblatt für die gesammte Unterrichts-Verwaltung in Preußen 8, no. 3 (1866), 148-50.

"Protocolle über die im August 1873 im Königlich Preussischen Unterrichts-Ministerium gepflogenen das mittlere und höhere Mädchenschulwesen betreffenden Verhandlungen." Centralblatt für die gesammte Unterrichts-Verwaltung in Preußen 15, no. 10 (1873), 569-636.

Schodrok, Karl-Heinz. Preussische Turnpolitik. Berlin: epubli, 2013.

Smith, Anthony D. Chosen Peoples: Sacred Sources of National Identity. Oxford: Oxford University Press, 2003.

Sombart, Werner. Händler und Helden: Patriotische Besinnungen. Munich/Leipzig: Duncker \& Humblot, 1915.

Spranger, Eduard. "An die Jugend." Der Säemann: Monatsschrift für Jugendbildung und Jugendkunde, 5 (1915), 386-93.

Stiehl, Ferdinand. Die drei Preußischen Regulative vom 1., 2. und 3. Oktober 1854 über Einrichtung des evangelischen Seminar-, Präparanden- und Elementarunterrichts. Berlin: Vilhelm Hertz, 1854.

Stiehl, Ferdinand. "Ausbildung von Turn-Lehrern für Elementarschulen." Centralblatt für die gesammte Unterrichts-Verwaltung in Preußen 7, nos. 9/10 (1865), 589-600.

Sydow, [unknown]. "Schrift von Gutzmann: Das Turnen der Taubstummen." Centralblatt für die gesamte Unterrichts-Verwaltung in Preußen, 20, no. 11 (1878), 626.

Tenorth, Heinz-Elmar. "The University of Berlin: A Foundation Between Defeat and Crisis, Philosophy and Politics." Bildungsgeschichte: International Journal for the Historiography of Education 4, no. 1 (2014), 11-28. 
Trott zu Solz von, August. "Einführung der dritten Turnstunde auf der Mittel und Oberstufe der Volksschulen; allgemeine Einführung der Übungen für das tägliche Turnen; Aufgaben des Turnunterrichts." Centralblatt für die gesamte Unterrichts-Verwaltung in Preußen 52, no. 7 (1910), 597-99.

Tröhler, Daniel. Pestalozzi and the Educationalization of the World. New York: Palgrave Pivot, 2013.

Tröhler, Daniel. "Educationalization of Social Problems and the Educationalization of the Modern World." In Encyclopedia of Educational Philosophy and Theory, edited by Michael A. Peters. Dordrecht: Springer, 2016.

Tröhler, Daniel. "Curriculum History in Europe: A Historiographic Added Value." Nordic Journal of Educational History 3, no.1 (2016), 3-24.

Villaume, Peter. "Von der Bildung des Körpers in Rücksicht auf die Vollkommenheit und Glückseligkeit des Menschen, oder über die physische Erziehung insonderheit." In Allgemeine Revision des gesammten Schul- und Erziehungswesens von einer Gesellschaft praktischer Erzieher, vol. VIII, 211-492. Vienna: Rudolf Gräffer und Compani, Schulbuchhandlung, 1787.

Wangemann, Hermann T. Schulordnung nebst Einrichtungs- und Lehrplan für die preussische Volksschule: Erste Abtheilung, welche die Schulordnung und die äusserlichen Einrichtungen betriff, zusammengestellt von Dr. Wangemann. Berlin: Wohlgemuth, 1856.

Weber, Georg H. Grundzüge des Turnunterrichts für Knaben und Mädchen in Volksund Mittelschulen; Ein Hilfs- und Handbuch für Schulbehörden, Lehrer und Turnlehrer. Munich: Zentral-Schulbücher-Verlag, 1881.

Wehler, Hans-Ulrich. Deutsche Gesellschaftsgeschichte - Dritter Band: 1849-1914. Munich: Beck, 1995.

Werner, Johann Adolf Werner. Gymnastik für die weibliche Jugend oder weibliche Körperbildung für die Gesundheit, Kraft und Anmuth. Meißen: Goedsche, 1834.

Werner, Johann Adolf Werner. Das ganze der Gymnastik oder ausführliches Lehrbuch der Leibeserziehung nach den Grundsätzen der besseren Erziehung zum öffentlichen und besonderen Unterricht. Meissen: Goedsche, 1834.

Wever, [unknown]. "Anleitung zum Knabenturnen in Volksschulen ohne Turnhalle." Centralblatt für die gesamte Unterrichts-Verwaltung in Preußen 51, no. 2 (1909), 241-43. 